\title{
VIEWS OF LEADING NURSE EDUCATORS REGARDING THE COMPREHENSIVE BASIC NURSING PROGRAMME
}

\author{
NS Gwele and LR Uys
}

\section{OPSOMMING}

Hierdie artikel beskryf ' $n$ Delphi opname onder verpleeg onderwysleiers in Suid Afrika. Die doel was om hut sieninge betreffende die redes vir die instel van die omvattende basiese verpleegprogram, die doel van hierdie program en die verwagle gevolge daarvan te beskryf.

Daar was algemene instemming dat die program nodig was, en dat dit ingestel is hoofsaaklik om ' $n$ verpleegkundige te produseer wat in staat is om in ' $n$ omvattende diens te funksioneer. Integrasie van inligting en ekonomiese oorwegings is ook genoem. Die voorsiening van verpleegkundige wat ' $n$ omvattende diens aan alle persone kan lewer, is danook gesien as die belangrikste doel, met onafhanklike leer, bemeestering van ' $n$ hele reeks vaardighede, die vernoë om in ' $n$ multidissiplinere span te werk en hoe vlak denkwaardighede as bykomende doelwitte.

Die implikasies van hierdie bevindinge word bespreek.

\section{ABSTRACT}

This article describes a Delphi survey amongst nurse educators in South Africa. The aim was to describe their perceptions regarding the reasons for the comprehensive basic nursing programme (CBNP), its aims and expected outcomes.

There was general agreement that the programme was necessary, and that it was designed mainly to produce a nurse who could function in a comprehensive health service. Integration of information and economic arguments were also mentioned. Making available a nurse who can deliver a comprehensive service to all people, was also seen as the main aim of the programme. Independent learning, competency in a whole range of skills, the ability to function in a multidisciplinary team and high level cognitive skills were mentioned as additional aims.

\section{INTRODUCTION}

In spite of the various attempts at reorganisation and change, problems facing nursing education in South Africa have remained more or less the same over a number of years. Uys (1991) presented a chronological account of the problems in nursing education from 1966 to 1987. Perusal of such problems exemplied by lack of correlation between theory and practice, multiple subject teaching for tutors, unavailability of tutors in the clinical seltings, and nursing students used as part of the workforce continue to haunt nursing education to the present day.

Uys observed that although some of these problems still exist, the nursing profession in South Africa has stopped complaining about them. She attributed the failure of the profession to attend to ourdated problems to nurse educators' tendency to criticise what is new, "probably because it demands so much more effort, initiative, and perseverance from the tutor $t w$ solve problems in a new way and to make new systems work" (Uys 1991,118).

Ef forts at reorganisation of nursing education in the country have been many and varied, but few, if any, have been subjected to any analysis. This study investigates the reasons. aims, and expected outcomes of the Comprehensive Basic Nursing Programme (CBNP).

\section{HACKGROUND}

The passing of the South African Nursing Council (SANC) regulations (R. 245 of 1985) sounded a death knell to the existing three and a half year basic nursing programmes in the country. Regulation 245 made it compulsory for all institutions involved in basic professional nurse preparation to reorganise their hasic nursing programmes so as to produce nurses qualified in midwifery. general-, psychiatric-and community health nursing within a 4-year programme.

For nearly 100 years, the preparation of professional nurses capable of functioning in a comprehensive health care system had been a long and repetitive ordeal. The South African nurse had to spend 6 to 7 years in nursing school in order to obtain these four clinical nursing qualifications. However, it $w$ as as early as 1945 when the SANC called for an end to the fragmented approach to professional nurse preparation (Searle, 1983; Woodward, 1991). Similar views were posited by Williamson after an extensive study of the American and South African systems of nursing education. Williamson recommended that "more integrated courses resulting in multiple registration be implemented" (Williamson 1977, 148). The duration of the fragmented programmes was not the only reason for this long overdue transformation in basic nursing education.

The CBNP was intended to be a solution to other problems facing nursing education at the time. Several authorities on nursing education in the country (Loudon, 1984; Nolte, 1985; Searle, 1983; Van Huyssteen. 1989) reiterated the SANC's concern about inadequate preparation of the country's nursing force with regard to the provision of comprehensive health care. It is important to note that the legislation that transformed the heatth care delivery system from a predominantly curative system, to a comprehensive health system was passed in 1977. In 1983, Searle $(1983,5)$ pointed out that, "statements by the various Ministers of Health that the Comprehensive Health System is built around the concept that nurses will be the main providers of health care" was one of the reasons for the establishment of the CBNP According to Loudon (1984) the graduates of the new programme would have varied, comprehensive knowledge, enabling them to function in any health care setting. However as a consequence of the fragmented approach to nurse preparation, of the total population of registered nurses available in South Africa in $1979.93 \%$ were general nurses and $73 \%$ were midwives. The two areas of clinical nursing which had been neglected were psychiatricand community health nursing. At the time, only $4.7 \%$ and $8.7 \%$ of all registered nurses held a registration in community health and 
psychiatric nursing respectively. By 1988 . these figures had risen respectively to $10.52 \%$ and $10.7 \%$ (Van Huyssteen, 1989).

Nevertheless, reason for concern as to whether or not the areas highlighted by Van Huyssteen (1989) as reasons for establishing the CBNP were receiving the adequate attention they deserve in nursing colleges was voiced by Alberts (1985). Alberts reported that of the nursing colleges which participated in her study, four responded to the section on her questionnaire that dealt with the new programme. Two of these colleges had already implemented the four-year programme. Alberts reported that there was documented evidence of planned over-teaching in at least three of the four clinical nursing subdisciplines, with general nursing science dominating the curriculum. For instance, while there was virtually no planned over-teaching for psychiatric nursing, the nursing colleges planned to increase the number of hours from $160 \mathrm{hrs}$ (as required by the SANC) to $389 \mathrm{hrs}(143 \%)$ for general nursing.

Feelings of discontent with the CBNP have been voiced both formally (at symposia and meetings of university heads of departments) and informally. Personal conversations with some members of the profession and some students have led the researcher to believe that the programme does not enjoy the same enthusiastic support it did at its inception.

It was exactly 5 years after the legislated establishment of the programme that Woodward (1991,3), a member of the SANC, lamented that "the reality of the demands created by the health needs of our society ... together with the complexities of the expectations regarding nurses and nursing, does place a tremendous strain on the continued relevance and credibility of our nursing education programmes". She pointed out that the evaluation strategies used by tutors are nothing but a "painful analysis of a technical skill in order to list its elements so that each can be accorded a mark on a sliding scale" (Woodward 1991,3). Similar concerns regarding the CBNP have been made Uys (1991) and Viljoen (1989). Viljoen identified the following unintended outcomes of the new programme as:- (a) limited opportunity for students to transfer from one college to another due to the different curricula, (b) difficulty in student selection, (c) reluctance of acceptance of students in clinical settings, especially in community health and psychiatric nursing, and (d) overloading of community health services with large numbers of students. These observations clearly are not in line with the philosophy of the SANC, which states that

The development of the ability for analytical, critical, evaluative and creative thinking and the stimulation of the exercise of interpretation, deduction and independent judgement of scientific dala for nursing actions are of urmost importance (Woodward, 1991.9).

\section{PURPOSE OF THE STUDY}

This study was carried out as an initial phase of a major project assessing the change process in nursing education. The aim of this phase of the project was to identify reasons, aims, and expected outcomes of the CBNP as perceived by those nurses directly involved in education. It was hoped that information gained through the Delphi method would pinpoint components of this programme about which leading nurse educators agreed. The components of the CBNP on which consensus was reached would therefore form a basis for the assessment phase of the change.

\section{OBJECTIVES OF THE STUDY}

The objectives of this study were to identify (a) reasons, aims, and expected outcomes of the CBNP, (b) teaching/learning activities which would hinder or facilitate attainment of expected outcomes, and (c) aspects of a curriculum that would facilitate or hinder attainment of the expected outcomes.

\section{METHODOLOGY}

This study is the first phase of a two-phase change assessment project. This phase of the study used a Delphi approach to identify the above mentioned objectives.

\section{SAMPLE AND SAMPLING PROCEDURE}

The targeted population included all the principals of nursing colleges, heads of nursing departments at universities offering the basic nursing programme $(N=44)$ and members of the South African Nursing Council $(\mathbf{N}=10)$ who were in office in 1983 . The decision to include the above mentioned groups of people was based on the belief that they play an important role in shaping basic nursing education in South Africa. Whereas the SANC members shape nursing education directly through regulations, principals of nursing colleges and heads of university nursing departments shape it by controlling the implementation process. For this study, this latter group was seen as leaders in nursing education.

\section{INSTRUMENTATION}

The Delphi consisted of three rounds of questionnaires. The first and the third round questionnaires consisted of open-ended questions. The first round questionnaire asked three questions relating to (a) whether respondents believed that the CBNP was necessary in South Africa, and (b) what they believed to be the aims and anticipated outcomes of a programme that had succeeded in achieving the identified aims.

For the second round of the Delphi, three rating scales were designed based on respondents' responses to the first questionnaire. Members of the panel were required to indicate whether they agreed or disagreed with the reasons and aims identified. Only those reasons and aims which were mentioned by two or more respondents were included in this round. This resulted in a five item five-point scale for reasons for the establishment of the CBNP and a 12 item five-point scale for the aims. The third rating scale involved rating of the identified expected outcomes as:- very important $=1$; important $=2$; would be nice if achieved $=3$; and not important $=4$. Of the 24 expected outcomes identified during the first round of the Delphi, only 10 were used for the second round.

The decision about using an identified expected outcome was based on it being mentioned by more than one member of the panel.

Data obtained from the second round of the Delphi were analysed and a third round questionnaire was designed based on this information. This was an open-ended questionnaire aimed at ascertaining

(a) whether the respondents believed that the four registrations awarded to the students on completion of the course were sufficient evidence for the expected outcome of producing nurses capable of rendering comprehensive health care,

(b) whether panel members believed that the graduates of the new programme would differ from graduates of previous South African basic nursing programmes, and

(c) means by which the attainment of the above objective could be assessed. Furthermore, the panel members were required to identify teaching and learming activities which would facilitate the attainment of this objective, as well as indicate features of a curriculum which would facilitate or hinder the attainment of this objective.

\section{DATA COLLECTION}

The 54 potential participants were contacted by mail in which the first round questionnaire and a covering letter explaining the nature of study, and requesting consent for participation, was included.

Of the $\mathbf{4 4}$ questionnaires mailed to principals of nursing colleges and heads of university nursing departments, only $20(45.5 \%)$ were returned. Fifteen of the returned questionnaires were usable. Returns from the ex members of the SANC were two, of which only one was usable. Although these returns are small, they were considered sufficient to yield the necessary information because (a) the Delphi approach requires commitment to participate in research, and (b) a population rather than a sample of the defined nurse leaders (all principals of nursing colleges and all heads of university nursing departments) was used.

For the second round 16 questionnaires were mailed to those panel members who had 
responded to the first questionnaire. At this stage, panel members were requested to respond to three rating scales. No attempt was made to follow up those subjects who had not responded to the first round of the study.

Based on information obtained from the second round, a third instrument, together with a summary of findings of the second round data was mailed to the 16 panel members who had participated in the second phase of the study. Only 13 respondents completed this round.

At this stage the number of panel members (13) who were still participating in the study had decreased remarkably. It was decided to terminate this phase of the study at the end of the third round for the following reasons:

(a) the information obtained from this phase was deemed adequate as a basis for assessing the implementation process, at least in terms of which components of the CBNP were perceived as important,

(b) responses regarding the nature of the teaching and learning activities that would hinder or facilitate attainment of the expected outcomes were stated in very broad and general terms in most cases, and therefore, did not provide any specifics in terms of what nurse educators should be doing in order to aid students' attainment of the expected outcomes.

\section{DATA ANALYSIS}

Data obtained from the three open-ended questions returned by panel members during the first round of the Delphi were analysed qualitatively. Depending on the nature of the responses, either sentences or paragraphs were used as units of analysis. Emphasis was mainly on contextual analysis which yielded 17 reasons, 23 aims and 24 expected outcomes for the CBNP. These aims and expected outcomes were further analysed quantitatively by means of frequency counts to identify items mentioned by more than one panel member. In all, five reasons, 12 aims and 10 expected outcomes were mentioned by more than one respondent. Second round data were analysed quantitatively in order to ascertain the level of agreement among panel members regarding the nature of the identified aims, as well as the degree of importance participants placed on identified expected outcomes.

The open-ended responses obtained from the third round were analysed both qualitatively and quantitatively. Qualitative analysis of data involved categorising responses according to similar themes, based on both sentences and paragraphs. Focus was on contextual or whole meaning of respondents' statements. Where outlines were given rather than open ended statements, an attempt was made to classify these according to existing categories obtained through the analysis of the open-ended responses.

TABLE 1 Ratings of Aims of the CBNP by Leading Nurse Educators $N=13$ (Second Round)

AIMS

Produce nurses capable of rendering comprehensive care to all patients and clients in institutions and communities

Educate and prepare nursing students to enter the nursing profession with competence in cognitive affective and psychomotor skills Develop independent leaming skills among nursing students

Produce nurses who would be able to work as members of a multi-disciplinary team

Facilitate personal and professional growth among nursing students

Shorten the duration of the basic training course and therelore, making it cost effective

Teach students to think critically, analytically, and creatively

Produce nurses who would be able to show respect for dignity and uniqueness of the individual in hisher socio-cultural context Improve the image of the nursing profession Integrate information

Enable diploma graduates to obtain university credits for some of the courses offered at nursing colleges

Produce nurses who would be able to render total patient care

\begin{tabular}{|c|c|c|c|c|}
\hline SA & A & $\mathbf{N}$ & DA & SD \\
\hline 10 & 3 & 0 & 0 & 0 \\
\hline 7 & 4 & 2 & 0 & 0 \\
\hline 7 & 4 & 2 & 0 & 0 \\
\hline 7 & 5 & 1 & 0 & 0 \\
\hline 7 & 4 & 1 & 0 & 0 \\
\hline 6 & 4 & 2 & 0 & 1 \\
\hline 7 & 5 & 1 & 0 & 0 \\
\hline 6 & 4 & 1 & 0 & 0 \\
\hline 5 & 2 & 5 & 1 & 0 \\
\hline 6 & 6 & 1 & 0 & 0 \\
\hline 5 & 1 & 4 & 1 & 2 \\
\hline 7 & 6 & 0 & 0 & 0 \\
\hline
\end{tabular}

\section{FINDINGS}

\section{NEED FOR THE CBNP IN SOUTH AFRICA}

Most (15) of the panel members who responded stated that there was a need for the comprehensive basic nursing programme in South Africa. The one respondent who did not believe that there was a need for this programme maintained that distinguishing devices accompanying course completion imply that the graduates of this programme are specialists in all four areas (general nursing, midwifery, psychiatric nursing, and community health nursing) whereas in actual fact "they are lacking in knowledge".

\section{REASONS AND AIMS FOR THE ESTABLISHMENT OF THE CBNP}

A total of 17 reasons for the need for the CBNP in South Africa was identified by respondents during the first round but only five of these were mentioned by more than one member of the panel

During the second round, unanimous agreement was reached on one reason only, namely the need to produce nurses capable of rendering comprehensive health care. Also, 11 of the 13 respondents who returned the second round questionnaires agreed that the need to integrate information and make nursing education more cost effective warranted establishment of the course. Consensus was reached by $50 \%$ of respondents on the need to shorten the period of nurse preparation as a reason for the establishment of the course.

Various aims (23) were identified. Twelve (12) of these were mentioned by two or more respondents during the first round of the Delphi. One aim viz. to produce nurses capable of rendering comprehensive health care to all patients and all clients was mentioned by 10 respondents in the first round. All respondents agreed with this aim in the second round. Ability to render comprehensive health care was rivalled by the need to produce nurses who would be able to render total patient care. A number of respondents (10-12) agreed that the development of (a) independent learning skills, (b) competence in cognitive, psychomotor, and affective skills, (c) ability to work as a member of a multidisciplinary health team, and (d) ability to think critically, creatively, and analytically, were aims. Table 1 depicts the 12 aims which were included in the second round.

\section{EXPECTED OUTCOMES OF THE CBNP}

The members of the panel identified 24 expected outcomes for the four year basic nursing programme. Of these 24 expected outcomes, 10 were mentioned by more than one respondent. Not surprisingly, ability to meet comprehensive service needs by the graduates of this programme was the most frequently mentioned expected outcome.

Four of the 10 expected outcomes included in 
TABLE 2 Ratings of Expected Outcomes of the CBNP by Leading Nurse Educators $\mathrm{N}=13$

\section{Expected Outcomes}

There would be a better match between the skills of the nurse practitioner and the needs of health services

There would be improved quality of nursing services (more patient and less procedure oriented)

Graduates of this programme would be able to:

Meet needs of people in health and sickness in all age groups within a comprehensive health service

Use independent judgement in nursing practice

Demonstrate competence as professional nurses in affective, cognitive, and psychomotor skills

Willingly participate in continuing education programmes

Emphasise community-based health care with resultant decrease in the number of hospitalised patients

Function in community, psychiatric, general hospital, and midwifery setting upon graduation

Apply the scientific approach to nursing

Think critically, analytically, and creatively

$\mathrm{VI}=$ Very Important; I = Important $\mathrm{WBN}=$ Would be nice if achieved: $N I=$ Not Importanl

the second round of the Delphi were rated as either very important or important by all members of the panel. A further five expected outcomes received the strong support of 10-12 respondents. Four members of the panel indicated that it would be nice if the expectation that there would be a better match between the skills of nurses and service needs was achieved. The ratings of the 10 expected outcomes of the CBNP appear on Table 2.

THE FOUR REGISTRATIONS AS INDICATIVE OF ATTAINMENT OF THE OBJECTIVE OF PRODUCING NURSES CAPABLE OF RENDERING COMPREHENSIVE HEALTH CARE

Six out of 13 panel members who participated in the third round of the Delphi maintained that the four registrations awarded by the SANC at the end of the students' four-year programme were sufficient proof that the objective of producing nurses capable of rendering comprehensive health care was attained. Four felt that this was not the case, whereas the remaining three were vague about this issue.

Those who responded affirmatively to this question asserted that because the curricula offered at the nursing colleges are approved by the SANC, and also the fact that the council carries out periodic inspection of nursing colleges, the four registrations were sufficient proof that this objective was attained. However, some of the respondents did not agree with this view. For instance, amongst those who were tentative about the issue one respondent stated:

In basic nursing - Yes. ... Of midwifery I'm not sure. Experience seems to be lacking. ...In community health and psychiatric nursing competency is not reached to the effect that students can practice [sic] in this field especially not in primary nursing. Their diagnostic skills are too poor.

The concern about the inadequacy of the preparation of the CBNP students in midwifery and psychiatric nursing was mentioned by three of these respondents.

Too much content in too short space of time, low standards of patient care, and lack of responsibility and dedication were some of the reasons offered for not accepting that the four registrations were indicative of a competent comprehensively trained nurse. A number of solutions to the perceived problems associated with this issue were offered which included the following: (a) internship (b) removal of the four registrations and (c) longer period in midwifery. The need to place the graduates of this programme through a period of internship was mentioned by three of the four non-assenting respondents.

\section{DIFFERENCES BETWEEN DIPLOMATES OF THE CBNP AND THOSE OF TRADITIONAL NURSING PROGRAMMES}

All of the respondents believed that the graduates of the CBNP would act differently from the graduates of the old diploma programmes. According to six of the 13 participants these nurses would be able to write more comprehensive nursing care plans, and make life easy for the nursing service manager in that they could be placed in any service setting upon graduation. Also it was indicated that the new graduates would be better able to integrate knowledge in rendering total patient care.

On a negative note, some of the respondents (4) believed that these nurses lack experience and therefore suffer from feelings of inadequacy, whereas graduates of old programmes were believed to be more competent upon graduation. The ambivalence about exactly what graduates of the CBNP should be doing differently became more succinct in a statement by one of the respondent:

In short I think they lack experience, therefore may feel inadequate. I also feel that they acquire only basic knowledge and need post-basic training. ... I do feel these students should be very carefully selected.

However, one of those who spoke positively stated that:

In actual fact in assessing diplomates from the four year programme after completion, they are more assertive, critical and logical reasoners ... some of them are now moving into leader positions.

\section{MEANS FOR ASSESSING THE ATTAINMENT OF THE PROGRAMME'S OBJECTIVE}

The need to follow up the graduates of this programme with evaluation studies focusing on their performance in their places of employment was identified by seven of the 13 respondents. Five respondents felt that an investigation into the students' own perceptions regarding their experiences and feelings of adequacy would reveal whether this objective was being met.

\section{TEACHING AND LEARNING ACTIVITIES THAT WOULD FACILITATE OR HINDER ATT AINMENT OF THE PROGRAMME'S OBJECTIVE}

The most frequently mentioned facilitative teaching and learning activities were (a) student accompaniment, (b) use of alternative clinical placements, (c) continuous evaluation, (d) staff development programmes for both ward and classroom staff (focusing mainly on alternative teaching approaches), and (e) use of a variety of teaching strategies, especially those that place emphasis on active participation on the part of the student. One respondent pleaded for the recognition of the ward sisters' involvement in the education of the nursing student.

In his/her own words:-

"The role of the ward sister has become a crucial factor - please! Compulsory updating of supervisors must be imple. mented to accommodate the student nurses. Funds again are the problem. Promotion should be given according to merits in training involvement."

The problem of outdated nurse educators in terms of developments in education was the only hindering factor identified by at least three respondents. 
FEATURES OF A CURRICULUM WHICH WOULD PROMOTE OR HINDER ATTAINMENT OF THE PROGRAMME'S OBJECTIVE

The features of the curriculum which were seen by at least five respondents as promoting attainment of the desired objective were:- (a) a totally integrated curriculum, (b) involvement of nurse educators in clinical teaching, (c) a problem-based curriculum, and (d) a community-based curriculum. Furthermore, a number of respondents (3) felt that this integration should occur as early as the planning of the curriculum.

One stated that:

Active involvement of all tutors that participate in teaching of students in the planning of micro-curriculum, and integration of knowledge/skills by all tutors who participate in teaching in the planning and implementation of the micro-curriculum of all subjects.

A number of aspects were identified as features that would hinder the attainment of this objective. Amongst others, these were (a) fragmented clinical placements, (b) emphasis on a number of lectures and clinical hours instead of competencies, (c) a packed and rigid curriculum with "too many nice to knows", and (d) enforced qualification in all four clinical areas. In fact one of the respondents had this to say:

The prescriptive attitude which is still
maintained by the SANC - hours are still
a problem ... certain learning experien-
ces can be learned through a modular
system - eg nental retardation with less
exposure to the actual clinical situation.
Students do not need to work for 160
hours in these situations, becone very
upset in some instances and having to
"endure" certain training mechanisms
which they have no intention to pursue
as part of their career. Male nurses in
mine hospitals may never use midwifery
and yet are conpelled to complete this
course. ... To my mind nothing is ac-
complished but an expensive training.

\section{DISCUSSION}

The reasons, aims and expected oulcomes of the CBNP as identified by the respondents did not differ from those appearing in South African nursing literature as well as those tabled by the SANC in the form of the objectives of this programme (R.425 of 1985). Although by the end of this phase, only 13 members were still participating, this is probably a representative figure for the leaders in this field. Firstly, the researcher had used a population of leading nurse educators in the country rather than a sample.

The SANC developers of the programme were asked to participate but chose not to. Therefore, it can be argued that the aims as identified by the participants in this study are the legitimate reasons, aims and expected outcomes of the CBNP.

The members of the panel all agreed that graduates of this programme should be able to render comprehensive health care, nurse holistically, think critically, analytically, and creatively. As if this was not enough, the nurse educators were fur ther called upon to foster the development of independent learning skills among these potential professional nurses. This list of expectations, although not exhaustive of the list of expected behaviours and skills closely resembles that appearing in the SANC's regulations as well as South African nursing literature.

The need to produce nurses capable of rendering comprehensive health care can be associated with the country's Health Act (Act No. 63 of 1977) which has shifted emphasis from a predominantly curative system to a comprehensive health care delivery system. Also literature abounds on the need to produce nurses capable of thinking critically, analytically, and creatively. The call made by the South African nursing community on the nurse educators is not specific to this country. Globally, basic nursing education progr ammes are being transformed in an effort to produce a more autonomous and independently thinking nurse. For example Project 2000, established in the early 1980s in the UK, the reorganisation in Israel of the nursing education system, and Australian efforts to place Australian nursing education in the academic arena, are but a few examples (Bevis \& Krulik, 1991; Parkes, 1984; Crotty. 1992). However, the call for all nursing colleges to adopt a holistic view of the person smacks of an imposition of a philosophical view of man on every nursing college's curriculum in the country.

Holistic nursing is derived from a philosophical perspective which emphasises the "wholeness of man" as opposed to a fragmented view of man. Analysts of nursing theories agree on the appeal of this perspective for nursing and nurses. However, they also agree on the difficulties that face curriculum planners in incorporating this perspective of man onto nursing curricula (Chinn \& Jacobs, 1987; Stevens, 1979). According to Chinn and Jacobs $(1987,49)$ " The concept of holism, ... dictates that no phenomena can be analyzed without residue into the sum of its parts or reduced to discrete elements". In this regard, Stevens $(1979,225)$ asserted that "Holistic man gives nursing a unique health-related subject matter, and, therefore, the potential to build a unique body of knowledge". It is now exactly 15 years since this statement was made but that unique body of knowledge has not materialised yet. Although Stevens $(1979,227)$ was quick to acknowledge that "There are, however, problerns in accepting holistic man as nursing's subject matter", due to the fragmented nature of nursing curricula. she argued for a nead for nursing to explore the potential of such an approach, but in line with an analyst's view of reality, did not provide any indicators as to how the nursing curriculum planners and teachers should attain this ideal. The question is, how far should an accrediting body be allowed to dictate a philosophical perspective as a basis for a country's nursing curricula? In other words how realistic is the concept of holistic nursing in terms of applicability to both clinical nursing and nursing education? Could this have been another bandwagon for the decision makers, whose destination was never questioned?

A number of factors were identified by the panel members as either facilitating or hindering the attainment of these objectives. A few referred to the problem of outdated nurse educators in terms of developments in education. Similar views were voiced by Crotty (1992) in relation to the role of the British nurse educator in Project 2000. In South Africa, this problem has permeated South African literature over a number of years. It is realised that this might really be a problem. However, no educational programme, including nurse teacher programmes can prepare an individual for life Moreover, as pointed out by Leino-Kilpi (cited in Crotty, 1992), even the current educational preparation of nurse educators does not prepare them for teaching a reflective curriculum. Judging by the demands the programme places on the nurse educator coupled with the fact that in most colleges, nurse educators still are expected to be experts in every subject (Uys, 1991), and the planned over-teaching in some colleges (Alberts, 1985), it is little wonder that the South African nurse educator finds it difficult to keep abreast of educational developments.

On a much more provocative note, Clare $(1993,283)$ asserted that "The rhetoric of nursing education reifies nursing ideals such as holistic caring, and reflective practice, and teaching strategies such as problem solving and experiential learning. This reification may even go so as far as to dismiss ... contradictions between classroom knowledge and the student's lived experiences in clinical placements, as personal and idiosyncratic rather than commonplace and collective".

Involvement of nurse educators in clinical teaching, a problem- and community- based curriculum were some of the facilitating features identified by the panel members. The plea for the nurse educator to be more involved in clinical teaching is a long and enduring issue in South Africa (Nolte, 1985, Uys, 1991). What is not clear is whether she had ever been given real opportunity to do so in terms of work load. Khumalo's findings based on a study examining the academic staffing patterns in nursing colleges in Transvaal and Natal, showed that scheduled teaching time. preparation, curriculum development meetings, marking of tests (often weekly) and examination papers, case studies and students' research reports took so much of the tutor's 52 hour work week that "clinical teaching 
appeared to be limited to an average of one to three hours per week, except for junior staff members of the academic staff with an average of four hours per week" (Khumalo 1992,43).

Despite the call for the nurse educator to be in the clinical situation, it is very doubtful that she had ever been accorded real opportunity to do so.

Conflicting views on whether or not the graduates of this programme were "better" prepared as professional nurses emerged from this study. One thing the members of the panel agreed upon was that there are or should be differences between the graduates of this programme and those of traditional programmes. Most of the areas of concern were those of competency in psychiatric nursing and community health nursing. The issue of problems of acceptability of the students in these clinical settings was reported by Viljoen (1989). Ironically, these are the very nursing areas which were seen as needing urgent attention in terms of manpower provision (Van Huyssteen, 1989). The complaints regarding the lack of competence in psychiatric- and community health nursing might be assigned to the fact that, previously, these were post-basic nursing courses. Therefore, nurse educators and the professional nurses in these clinical settings were used to a maturer nursing student.

The task of a professional regulating body is a very difficult one. The SANC has strived through the years to maintain high educational standards in nursing but this has not been without cost to the Council's image in the profession. A few of the panel members complained that the SANC was still too restrictive.

Perusal of the Council's regulations revealed that this professional regulating body takes a very detailed interest in the nursing colleges' curricula. The SANC is very specific in terms of how a student planning to be a professiona nurse is supposed to spend his/her time, from detailed specification of a number of lectures for each subject, specified core curriculum, to specified number of hours of clinical practice for each clinical nursing subdiscipline. No wonder then that some of the panel members found these requirements too restrictive. Uys (1991) maintained that the Nursing Council encourages innovation. Yet it should be remembered that "diversity and the accompanying freedom to innovate, experiment, and do one's own thing, like any form of liberty, are always possible only in conditions where freedom is allowed" (The Carnegie Foundation for the Advancement of Teaching, 1979, 41). In contrast, Viljoen (1989) suggested that the nursing colleges were in fact given too much freedom by the SANC. This dilemma pervades the professional regulating bodies of a range of professions (Levine, 1978).

Additional research is needed to examine the perceptions of the students and diplomates of this programme regarding their experiences both in classroom and clinical learning contexts. Some members of the panel recommended that a period of internship for the diplomates of the CBNP would help alleviate some of the problems experienced by these nurses on their first appointments as registered nurses.

Review of the national "basic standards" as well as local curricula may help rid the programme of some the areas seen as "nice to knows'. The profession needs to re-examine the value it places on clinical teaching. This might necessitate total restructuring of clinical teaching posts so as accord the clinical instructor the same status as the tutor. In this way, this essential aspect of preparing individuals for professional practice might be treated with all the significance it deserves. Finally all those who are involved in the education of students need to be involved in curriculum planning and decision making at all levels of planning.

\section{REFERENCES}

Alberts, U.U. (1985) . Dieimplementering van die SARY se leerplane deur enkele verpleegkolleges en-skole. Pretoria: UNISA

Bevis, E. O., \& Krulik, T. (1991). Nationwide faculty development for a shift from diploma to baccalaureate education. Journal_ of Adyanced Nursing 16. 362-370.

Carnegie Foundation for the Advancement of Teaching. (1979). Missions of the college curriculum: A contemporary review with suggestions. San Francisco: Jossey Bass.

Chinn, P. L., \& Jacobs, M. K. (1987). Theory and nursing: Asystematic approach. St Louis: C. V. Mosby.

Clare, J. (1993). Change the curriculum - or transform the conditions of practice? Nurse Education Today 13(4), 282- 286.

Crotty, M. (1992). The perceptions of nurse teachers regarding the preparation for their role in Project 2000 programmes. Nurse Education Today 12.350-356.

Khumalo, E. T. (1992). Academic staffing patterns in nursing colleges in Natal and Transyaal. Masters Thesis, Durban: University of Natal.

Levine, A. (1978). Handbook on undergraduate curriculum.San Francisco: Jossey Bass.

Loudon, H. (1984). Trends in nursing in South Africa and their implications for nursing education. Curationis, 2 8-11.

Nolte, A. G. W. (1985). Die opleidine yan die yroedvrou in Suid Afrika (DLitt et Phil). Pretoria: UNISA
Parkes, M. (1984, Feb. 01). New directions in Australia. Nursing Times 80 59-6r.

Searle, C. (1983). New dimensions: Nursing education in the post-secondary system in the Republic of South Africa. Curationis, 6. 4-9.

South African Nursing Council. (1985, Feb.). B. 425: Regulations relating to approyal and the minimum requirements for the education and training of a nurse (general psychiatric and community) and midwife leading to repistration Pretoria: SANC.

Stevens, B. J. (1979). Nursing theory: Analysis, application, evaluation Boston: Little \& Brown.

Uys, L. R. (1991). Nursing Education. In L. R Uys \& W. J. Kotze' (Eds.) State of the art of nursing: A centenary publication (pp 133-145). Pretoria: SANA

Van Huyssteen, M. C. (1989, September). Die rasionaal agter die instelling van die vier jaar geintegreerde kurses wat lei tot registrasie by die Suid Afrikaanse Raad op Verpleeging as verpleegkundige en vroedvrou. A paper presented at a symposium entitled Yoorwarts: 'N D4 perspektief. Hosted by Ann Latsky nursing college.

Viljoen, J. M. (1989, September). Instelling van die D4- kursus in die Kaapprovinsie. A paper presented at a symposium entitled Voorwarts: 'N D4 perspektief Hosted by Ann Latsky-Verpleegingskollege.

Williamson, S. B. (1977). A comparative study of nursingeducation in the United States of America and the Republic of South Africa. Pretoria: SANA.

Wood, R. J. (1990). Changing the educational program. New Directions in Higher Education. 18(172), 51-58

Woodward, V. (1991, June). The state of nursing education. A paper presented at symposium entitled Nursing education: In touch with reality Hosted by the Nursing Department, University of Natal.

NS Gwele PhD
Senior Lecturer
UNIVERSITY OF NATAL
Durban
LR Uys
D Soc Sci (Psychiatric Nursing)
Head of Department: Nursing
UNIVERSITY OF NATAL
Durban

The authors acknowledge with thanks the help given by nurse educators who participated in this stukly. 